\title{
First record of Calappoidea and Dromioidea from the Upper Cretaceous (Upper Maastrichtian) of NW Madagascar
}

\author{
Alessandro Garassino ${ }^{1} \&$ Giovanni Pasini ${ }^{2}$ \\ ${ }^{1}$ Dipartimento di Paleontologia degli Invertebrati, Museo civico di Storia naturale, C.so Venezia 55, I-20121 \\ Milano, Italy; ${ }^{2}$ Museo Civico dei Fossili di Besano, Via Prestini 5, I-21050 Besano (Varese), Italy
}

Keywords: Crustacea, Decapoda, Cretaceous, Madagascar

\begin{abstract}
The crustaceans from the marine Berivotra Formation, dated as late Cretaceous, from $50 \mathrm{~km}$ south of Mahajanga, Madagascar contains macrurans, brachyurans and thalassinideans. Two brachyuran families, Raninidae and Dynomenidae, were previously identified with the genera Notopocorystes, Caloxanthus, Titanocarcinus, Xanthosia, and Dromiopsis. Fragmentary material now also allows the recognition of Dromioidea, Calappoidea and Xanthoidea.
\end{abstract}

\section{Introduction}

The present sample originates from the vicinity of the village of Berivotra, c. $50 \mathrm{~km}$ south of the city of Mahajanga, along National Road 4 towards Antananarivo, NW Madagascar. This area is usually referred to as the 'Mahajanga Basin' (Besairie, 1972). The specimens represent surface finds, from the eroded sides of low hills not exceeding $250 \mathrm{~m}$ in height, situated to the east and west of Berivotra and close to its cemetery, to the west of the village.

The material studied comes from the marine Berivotra Formation, dated as late Cretaceous (late Maastrichtian) (Krause \& Hartman, 1996; Krause et al., 1997, 1999). The lower part of this unit is characterized by a rich assemblage of grypheid and ostreid bivalves, decapod crustaceans, shark teeth, teleost fragments, and interambulacral plates and primary spines of regular echinoids. The upper portion yields a fauna comprising bivalves, neogastropods, cephalopods, echinoderms and chondrichthyan fish.

\section{Results}

To date, the sole study of decapod faunas from the Cretaceous of Madagascar is that by Secretan (1964), who described material from the Lower and Middle Cretaceous of the Sitampiky Basin and the Analalava area and from the Üpper Cretaceous of the Menabé and Mangoky-Onihaly areas (SW Madagascar). She listed macrurans, brachyurans and thalassinideans. Two brachyuran families (Raninidae, Dynomenidae) were identified from the Lower and Middle Cretaceous, with Notopocorystes, Xanthosia (sic; compare Secretan, 1964) and Dromiopsis, while the Upper Cretaceous strata yielded raninids (Notopocorystes), dynomenids, xanthids (Xanthosia, Caloxanthus, Titanocarcinus) as well as an unidentified xanthid.

The present sample comprises a total of 191 specimens, consisting of cheliped fragments, mostly dactyli and fixed fingers. The absence of complete chelae may possibly be ascribed to decay rather than to transport, which determines the degree of fragmentation and disarticulation after several weeks, as pointed out by Allison (1990). Since the specimens are fragmentary, they can only be assigned to larger groups; only in a few cases was it possible to identify them to lower taxonomic levels by comparison with already known fossil genera. The material represents the Calappoidea and Dromioidea, both recorded for the first time from the Cretaceous of Madagascar (Fig. 1). In addition, we have numerous specimens referred to as Xanthoidea (fam. gen. et sp. indet.) and three groups $f$ isolated cheliped elements (incertae sedis). 

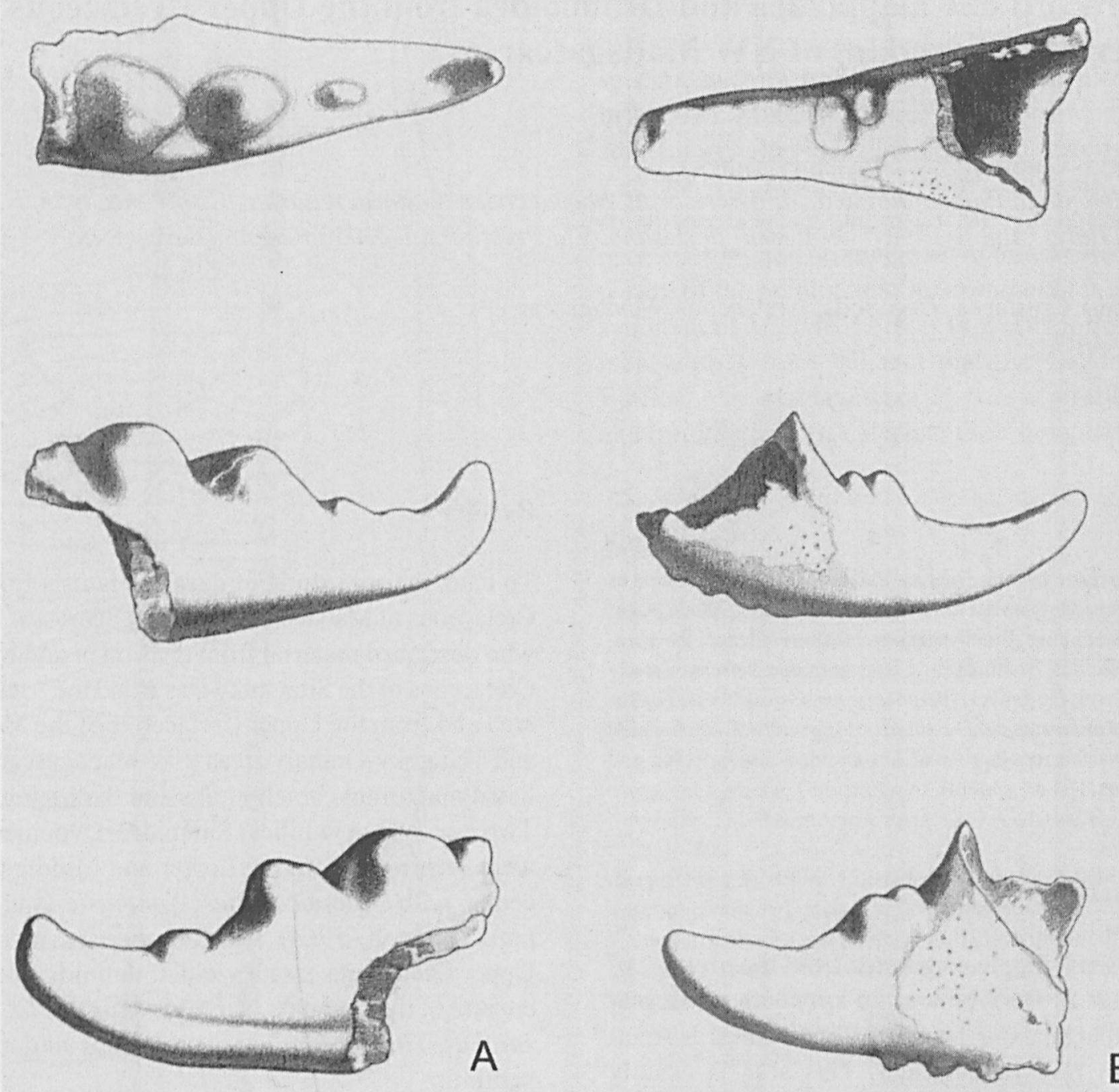

Fig. 1. A - Dromioidea indet., fixed finger of right chela (occludent view, outer and inner surfaces, respectively); B - Calappoidea indet., dactylus of right chela (occludent view, outer and inner surfaces, respectively).

\section{References}

Allison PA. 1990. Decay processes. In: Palaeobiology, a synthesis: 213-216. Oxford: Blackwell Scientific Publications.

Besairie H. 1972. Géologie de Madagascar, 1. Les terrains sédimentaires. Ann. Géol. Madagascar 35: 170, 171.

Krause DW, Hartman JH. 1996. Late Cretaceous fossils from Madagascar and their implications for biogeographic relationships with the Indian subcontinent. In: Sahni A. (ed.). Cretaceous stratigraphy and palaeoenvironments. Mem. geol. Soc. India 37: 135-154.

Krause DW, Hartman JH, Wells NA. 1997. Late Creta- ceous vertebrates from Madagascar: implications for biotic change in deep time. In: Patterson B, Goodman S. (eds.). Natural change and human impact in Madagascar: 3-43. New York: Smithsonian Institution Press.

Krause DW, Rogers R, Foster CA, Hartman JH, Buckley GA, Sampson SD. 1999. Late Cretaceous vertebrate fauna of Madagascar: implications for Gondwanan paleobiogeography. GSA Today 9: 1-7.

Secretan S. 1964. Les crustacés décapodes du Jurassique et du Crétacé de Madagascar. Mém. Mus. natn Hist. nat. Paris C14: 1-224.

Received: 2 March 2003 